\title{
Antioxidant and anti-inflammatory activity of Ocimum labiatum extract and isolated labdane diterpenoid
}

Petrina Kapewangolo ${ }^{1,3}$, Justin J Omolo ${ }^{2,4}$, Ronel Bruwer ${ }^{1}$, Pascaline Fonteh ${ }^{1}$ and Debra Meyer ${ }^{1,5^{*}}$

\begin{abstract}
Background: Plants from the genus Ocimum are used as folk medicine for treating various diseases including inflammatory and immune-related diseases. Numerous reports have suggested plant extracts and their constituents as possible anti-inflammatory agents. Here, in vitro evidence of Ocimum labiatum's immune-enhancing and antioxidant properties is presented for the first time.

Methods: The anti-inflammatory effect of $O$. labiatum ethanolic extract and an isolated diterpenoid was determined using a cytometric bead array (CBA) technique. The effect on phytohemagglutinin (PHA)-induced nitric oxide (NO) production in peripheral blood mononuclear cells (PBMCs) was also assessed. A battery of antioxidant assays were used for detecting antioxidant activity while the anti-inflammatory mechanism was evaluated using an ELISA-based activator protein (AP-1) (c-Jun) assay. Cytotoxicity was determined on TZM-bl and PBMCs using a tetrazolium dye and confirmed by a novel label-free real-time assay.
\end{abstract}

Results: A $25 \mu \mathrm{g} / \mathrm{mL}$ non-cytotoxic concentration of 0 . labiatum extract significantly $(p<0.05)$ inhibited the production of pro-inflammatory cytokines; IL-2, IL-4, IL-6 and IL-17A. Except for the dual acting pro- or anti-inflammatory cytokine, IL-6, which was upregulated, a non-cytotoxic $50 \mu \mathrm{M}$ concentration of the isolated labdane diterpenoid compound significantly $(p<0.05)$ decreased the production of all the pro-inflammatory cytokines. In the anti-inflammatory pathway studies, the compound also inhibited AP-1 significantly $(p<0.05)$ at $50 \mu \mathrm{M}$. The extract demonstrated strong, dose dependent antioxidant activity with $I C_{50}$ values ranging from $13 \pm 0.8$ to $54.86 \pm 1.28 \mu \mathrm{g} / \mathrm{mL}$ while the terpene had no antioxidant property. The extract and diterpenoid decreased the production of the inflammatory mediator $\mathrm{NO}$, at non-cytotoxic concentrations. The $C_{50}$ of the extract in TZM-bl and PBMCs was $62.6 \pm 0.6$ and $30.1 \pm 0.4 \mu \mathrm{g} / \mathrm{mL}$ while that of the compound was $112.6 \pm 0.2$ and $70 \pm 0.4 \mu \mathrm{M}$ respectively. The real time studies confirmed tetrazolium dye assessed viability and also detected a unique growth pattern for the plant materials compared to untreated cells.

Conclusions: $O$. labiatum extract demonstrated promising anti-inflammatory and antioxidant properties while the terpenoid showed anti-inflammatory but no antioxidant activity. The anti-inflammatory mechanism of the terpene was a result of inhibition of AP-1. These data represents promising first steps towards the development of naturally derived anti-inflammation drugs.

Keywords: Ocimum labiatum, Labdane diterpenoid, Inflammatory cytokines, Nitric oxide, Antioxidant, AP-1

\footnotetext{
* Correspondence: dmeyer@uj.ac.za

${ }^{1}$ Department of Biochemistry, Faculty of Natural and Agricultural Sciences,

University of Pretoria, Hatfield Campus, Pretoria 0002, South Africa

${ }^{5}$ Present address: Department of Biochemistry, Faculty of Sciences, University

of Johannesburg, P.O. Box 524, Auckland Park, Johannesburg 2006, South

Africa

Full list of author information is available at the end of the article
}

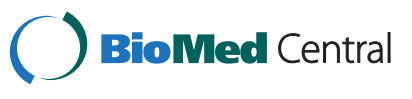

(c) 2015 Kapewangolo et al.; licensee BioMed Central. This is an Open Access article distributed under the terms of the Creative Commons Attribution License (http://creativecommons.org/licenses/by/2.0) which permits unrestricted use, distribution, and reproduction in any medium, provided the original work is properly credited. The Creative Commons Public Domain Dedication waiver (http://creativecommons.org/publicdomain/zero/1.0/) applies to the data made available in this article, unless otherwise stated. 


\section{Background}

The majority $(60 \%)$ of approved drugs are either directly isolated or derived from natural products [1]. Ocimum labiatum, commonly known as 'pink sage', belongs to the Lamiaceae family and is widely distributed in Southern Africa [2]. The plant is indigenously used for medicinal purposes, mostly antimicrobial [2,3]. Plants from the Ocimum genus are used traditionally to alleviate various disease symptoms such as pain, fever and inflammation, and the pharmacological activities of some extracts of these plants have been studied in vitro or in vivo without identifying the bioactive components [4-7].

Lamiaceae plants are generally rich in terpenoids; a diverse class of naturally occurring organic-chemicals derived from five-carbon isoprene units. Plant isolates containing terpenoids have been found to suppress nuclear factor kappa B (NF- $\kappa \beta)$ signalling [8], a protein complex linked to the pathogenesis of inflammatory diseases, cancer, viral infection and autoimmune diseases [8]. In another study, semisynthetic labdane diterpenoid derivatives reportedly suppressed NF- $\kappa \beta$ and nitric oxide (NO) production in macrophages [9]. $\mathrm{NO}$ is an inflammatory molecule produced by inducible NO synthase in macrophages and plays a role in immunoregulation $[10,11]$. Inhibitors of NO might be of therapeutic importance in preventing pathological conditions catalysed by inflammation [9-11]. Investigations of labdane diterpenoids suggest these compounds to have potential as alternative treatment for inflammatory diseases and further investigation is needed to identify the exact mechanism of action and pathways that are modulated by these compounds. Two labdane diterpenoid compounds were isolated from O. labiatum by Hussein et al. (2007) one of which inhibited Mycobacterium tuberculosis and the other demonstrated moderate anti-cancer properties both in vitro [12].

Plants from the Lamiaceae family are considered to be good sources of antioxidants due to the presence of high concentrations of phenolic compounds [13,14]. Antioxidants have the ability to dismutate reactive oxygen species (ROS) which are produced by the oxidation processes in various cells. Oxidative stress, caused by the accumulation of ROS in animal tissues, is a major cause of cell damage or death and is considered an instrumental process that leads to various cancers and other diseases [15]. In addition, ROS in low concentrations act as significant cell signalling molecules and regulates the biological conditions of cytokines, hormones and growth factors. High levels of free radicals, however, overcome the normal cellular antioxidant defences and end up being cytotoxic to the biological system [16]. These cumulative ROS are associated with a number of diseases including chronic inflammatory diseases [17-19]. ROS have also been reported to be involved in the activation of NF- $\kappa \beta$ by pro-inflammatory cytokines such as Tumour necrosis factor (TNF)- $\alpha$ [16]. Given the importance of activated NF- $\kappa \beta$ in inflammatory disease progression, suppression of this protein directly or through inhibition of ROS or pro-inflammatory cytokines preferably by antioxidants, remain therapeutically important because of the ability of the latter to combat pathogenic chain reactions initiated by free radicals.

The activator protein 1 (AP-1) is another transcription factor which regulates inflammatory cytokines and thus is being targeted as a way of circumventing inflammation [20]. AP-1 consist of dimeric transcription factors namely Jun, Fos and ATF subunits [21]. Inhibition of the c-Jun component of AP-1 results in the prevention of transcription of inflammatory genes and hence inflammatory cytokines since AP- 1 is prevented from binding to transcription factors in the nucleus [22].

The onset of common human diseases such as autoimmunity and chronic infections is characterized by a dysregulation of the T helper cell type 1 (Th1) and Th2 cytokine balance [23]. Interleukin (IL)-6 has been reported to be responsible for Th17 cells induction to secrete IL-17, a pro-inflammatory cytokine [24]. Since cytokines are central mediators in major inflammatory diseases and impact one another's production and action [23], it is important to simultaneously measure more than one cytokine from all 3 subsets; Th1/Th2/Th17. This will allow for better assessment of immune and inflammation status with these proteins as potential indicators in prognostic and drug discovery studies [23,25].

Although many species of the Ocimum genus have been extensively investigated in vitro, this is not the case with O. labiatum. In this study, O. labiatum was investigated for anti-inflammatory properties through inhibition or suppression of pro-inflammatory cytokines using the human Th1/Th2/Th17 cytometric bead array assay which allows for the quantification of multiple cytokines in a single sample. The effect of O. labiatum on $\mathrm{NO}$ production was also evaluated because there is ongoing research for potential anti-inflammatory agents from nature due to adverse side effects and high costs of existing anti-inflammatory drugs [26]. The antioxidant potential of $O$. labiatum as well as the anti-inflammatory pathway was also investigated.

\section{Methods}

\section{Plant extraction and compound isolation}

Fresh leaves $(894.6 \mathrm{~g})$ of O. labiatum were collected during February (2012) from the Botanical garden of the University of Pretoria. Plant identification was done in the H.G.W.J Schweikerdt herbarium of the University and a voucher specimen (117693) is kept in the herbarium.

Fresh leaves were blended in ethanol and filtered. The filtrate was evaporated under reduced pressure at $50^{\circ} \mathrm{C}$ using a rotary evaporator (Buchi, Flawil, Switzerland) 
and the residue was dissolved in ethyl acetate to obtain a lipophilic fraction. The ethyl acetate fraction was transferred to a pre-weighed vial and was evaporated to dryness at room temperature. The dried extract was stored in the dark at $4^{\circ} \mathrm{C}$ until use. The extract was weighed out as needed and reconstituted in dimethyl sulfoxide (DMSO) before each biological assay. Reconstituting in DMSO surface sterilized the extract. Further dilutions to the desired extract concentrations were done in either cell culture media or buffer depending on the type of biological assay performed.

The ethyl acetate fraction $(31.1 \mathrm{~g})$ was subjected to column chromatography (Si gel 70-230 mesh) eluting with hexane $(1.5 \mathrm{~L})$ then with hexane-ethyl acetate (9:1, 4:1, 7:3, 3:2, 1:1, 3:7; $1.5 \mathrm{~L}$ each) and finally with ethyl acetate $(1.5 \mathrm{~L})$, collecting fractions of $500 \mathrm{~mL}$ each. The last fraction, with $100 \%$ ethyl acetate, yielded a pure compound in the form of white crystals $(65 \mathrm{mg})$.

Labda-8(17),12E,14-triene-2R,18-diol (Figure 1): White crystals $\left(\mathrm{C}_{20} \mathrm{H}_{32} \mathrm{O}_{2}\right) ;{ }^{1} \mathrm{H}$ NMR $\left(\mathrm{CDCl}_{3}, 500 \mathrm{MHz}\right): \delta 6.32$ $(1 \mathrm{H}, \mathrm{dd}, \mathrm{J}=10.5,17.5 \mathrm{~Hz}, \mathrm{H}-14), 5.40(1 \mathrm{H}, \mathrm{t}, \mathrm{J}=6.0$, $12.5 \mathrm{~Hz}, \mathrm{H}-12), 5.05(1 \mathrm{H}, \mathrm{d}, \mathrm{J}=17.5 \mathrm{~Hz}, \mathrm{H}-15 \mathrm{a}), 4.88$ $(1 \mathrm{H}, \mathrm{d}, \mathrm{J}=11.0 \mathrm{~Hz}, \mathrm{H}-15 \mathrm{~b}), 4.86(1 \mathrm{H}, \mathrm{d}, \mathrm{J}=1.5 \mathrm{~Hz}$, $\mathrm{H}-17 \mathrm{a}), 4.49(1 \mathrm{H}, \mathrm{d}, \mathrm{J}=1.0 \mathrm{~Hz}, \mathrm{H}-17 \mathrm{~b}), 3.97(1 \mathrm{H}, \mathrm{m}$, $\mathrm{H}-2), 3.42(1 \mathrm{H}, \mathrm{d}, \mathrm{J}=11.0 \mathrm{~Hz}, \mathrm{H}-18 \mathrm{a}), 3.18(1 \mathrm{H}, \mathrm{d}, \mathrm{J}=11$ Hz, H-18b), 2.38 (1H, m, H-11a), 2.37 (1H, m, H-11b),

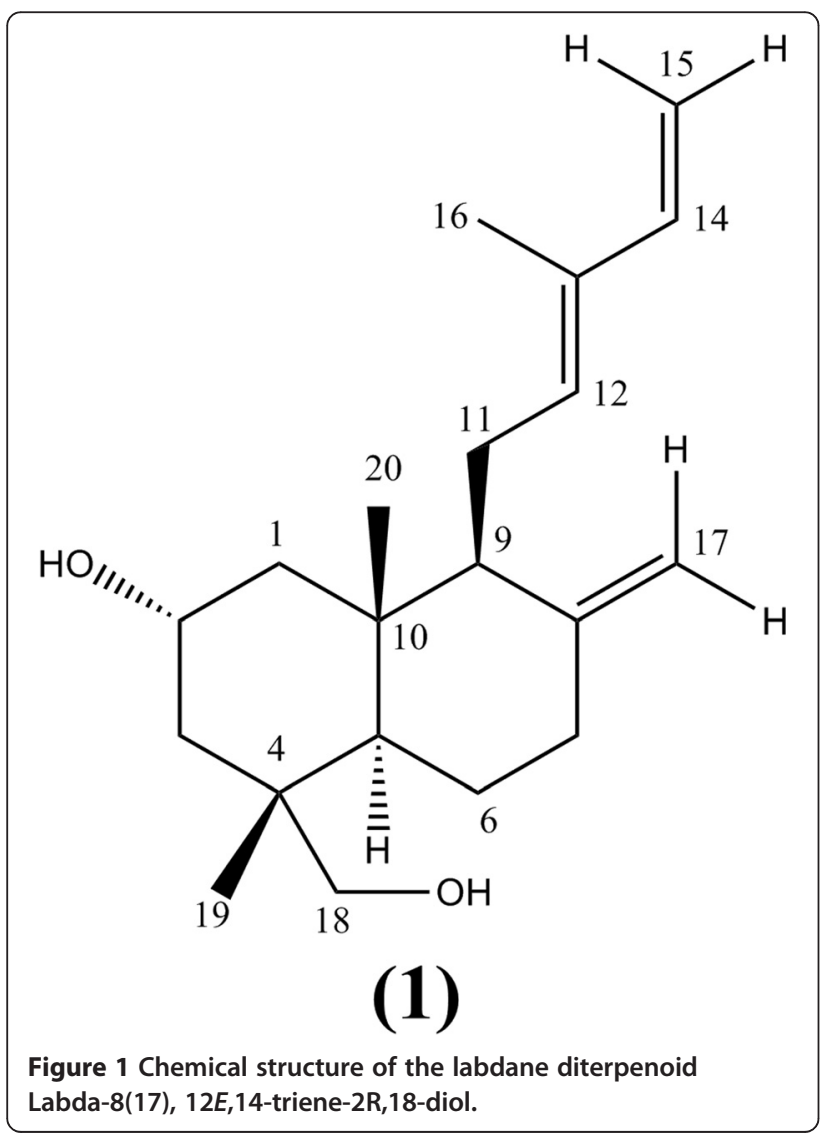

$2.03(2 \mathrm{H}, \mathrm{m}, \mathrm{H}-7), 1.88(1 \mathrm{H}, \mathrm{d}, \mathrm{J}=10.5 \mathrm{~Hz}), 1.75(3 \mathrm{H}, \mathrm{s}$, $\mathrm{H}-16), 1.63(2 \mathrm{H}, \mathrm{m}, \mathrm{H}-6), 1.47$ (1H, dd, J = 2.5, $12.5 \mathrm{~Hz}$, $\mathrm{H}-5), 1.41(2 \mathrm{H}, \mathrm{d}, \mathrm{J}=11.5 \mathrm{~Hz}, \mathrm{H}-3), 1.05(2 \mathrm{H}, \mathrm{t}, \mathrm{J}=11.5$, $23.0 \mathrm{~Hz}, \mathrm{H}-1), 0.81$ (3H, s, H-20), 0.80 (3H, s, H-19); ${ }^{13} \mathrm{C}$ NMR $\left(\mathrm{CDCl}_{3}, 125 \mathrm{MHz}\right): \delta 147.4(\mathrm{C}, \mathrm{C}-8), 141.5(\mathrm{CH}$, $\mathrm{C}-14), 133.6$ (C, C-13), $133.4(\mathrm{CH}, \mathrm{C}-12), 110.0\left(\mathrm{CH}_{2}\right.$, C-15), $108.5\left(\mathrm{CH}_{2}, \mathrm{C}-17\right), 71.5\left(\mathrm{CH}_{2} \mathrm{OH}, \mathrm{C}-18\right), 65.5$ $(\mathrm{CHOH}, \mathrm{C}-2), 56.8(\mathrm{CH}, \mathrm{C}-9), 47.9\left(\mathrm{CH}_{2}, \mathrm{C}-1\right), 47.5$ (CH, C-5), $44.6\left(\mathrm{CH}_{2}, \mathrm{C}-3\right), 40.7$ (C, C-10), 39.4 (C, C-4), $37.5\left(\mathrm{CH}_{2}, \mathrm{C}-7\right), 23.5\left(\mathrm{CH}_{2}, \mathrm{C}-6\right), 23.3\left(\mathrm{CH}_{2}, \mathrm{C}-11\right), 18.5$ $\left(\mathrm{CH}_{3}, \mathrm{C}-19\right), 15.8\left(\mathrm{CH}_{3}, \mathrm{C}-20\right), 11.8\left(\mathrm{CH}_{3}, \mathrm{C}-16\right) ; \mathrm{MS} \mathrm{m} / \mathrm{z}$ 304.2402 (calculated for $\mathrm{C}_{20} \mathrm{H}_{32} \mathrm{O}_{2}\left[\mathrm{M}^{+}\right]$304.2402).

The ${ }^{1} \mathrm{H}$ and ${ }^{13} \mathrm{C}$ NMR spectra of compound 1 displayed resonances for an exocyclic methylene group $\mathrm{H}-17$ at $\delta$ $4.86(1 \mathrm{H}, \mathrm{d}, 1.5)$ and $4.49(1 \mathrm{H}, \mathrm{d}, 4.49)$ both attached to carbon at $\delta 108.5$. The spectra further showed the presence of C-9 side chain which was identical to those reported data by Hussein et al., 2007. The ${ }^{1} \mathrm{H}$ NMR spectra showed the presence of methine proton in a cyclohexane ring at $\delta 3.97(1 \mathrm{H}, \mathrm{m})$, placed between two methylene substituents at $\delta 1.05(2 \mathrm{H}, \mathrm{t}, 11.5,23.0)$ and $1.41(2 \mathrm{H}, \mathrm{d}, 11.5)$, suggesting $\mathrm{C}-2$ was attached to a hydroxyl substituent, possibly as part of the labdane hydrocarbon skeleton. The spectroscopic data showed an $\mathrm{AB}$ system at $\delta 3.42$ and $3.18(1 \mathrm{H}, \mathrm{d}, \mathrm{J}=11.0$ each $)$ of hydroxymethylene group attached to quaternary carbon C-4 $(\delta 71.5)$. The position of the hydroxyl group at the $\mathrm{C}-18(\delta 71.5)$ was further confirmed by the HMBC spectrum which showed correlation between the hydoxymethylene protons and the $\mathrm{C}-3$ ( $\delta$ 44.6), C-4 ( $\delta$ 39.4), C-5 ( $\delta$ 47.5) and C-19 ( $\delta$ 18.5).

The ${ }^{13} \mathrm{C}$ NMR and DEPT spectra showed the presence of twenty carbon signals. These included, four quaternary carbons $\mathrm{C}-4, \mathrm{C}-8, \mathrm{C}-10$ and $\mathrm{C}-13$ at $\delta 39.4,147.4$, 40.7 and 133.6 respectively; one oxymethine carbon $\mathrm{C}-2$ at $\delta 65.5$; four methine carbons $\mathrm{C}-5, \mathrm{C}-9, \mathrm{C}-12$ and $\mathrm{C}-14$ at $\delta 47.5,56.8,133.4$ and 141.5 respectively; one oxymethylene carbon $\mathrm{C}-18$ at $\delta 71.5$; seven methylene carbons $\mathrm{C}-1, \mathrm{C}-3, \mathrm{C}-6, \mathrm{C}-7, \mathrm{C}-11, \mathrm{C}-15$ and $\mathrm{C}-17$ at $\delta 47.9$, 44.6, 23.5, 37.5, 23.2,110.0 and 108.5 respectively; and three methyl carbons C-16, C-19 and C-20 at $\delta 11.8$, 18.5 and 15.8 respectively as shown in Table 1.

The COSY spectrum depicted mostly correlations of the adjacent protons $\mathrm{H}-11 \mathrm{a}, \mathrm{b} ; \mathrm{H}-14 \mathrm{a}, \mathrm{b} ; \mathrm{H}-17 \mathrm{a}, \mathrm{b}$ and $\mathrm{H}-18 \mathrm{a}, \mathrm{b}$. From the NMR spectroscopic data the molecular formula of compound 1 was determined to be $\mathrm{C}_{20} \mathrm{H}_{32} \mathrm{O}_{2}$, corresponding to a theoretical exact mass of 304.24. The MS data showed a molecular ion $\mathrm{M}^{+}$peak at $\mathrm{m} / \mathrm{z} 304.24$ confirming the structure of compound 1 . The ${ }^{1} \mathrm{H}$ and ${ }^{13} \mathrm{C}$ NMR spectroscopic data for compound 1 compared well with literature data [12].

\section{Viability of TZM-bl cells using MTT}

The effect of O. labiatum extract and isolated compound on the viability of TZM-bl cells was determined 
Table 1 NMR spectral assignments for compound 1

\begin{tabular}{|c|c|c|c|c|}
\hline $\begin{array}{l}\text { Carbon } \\
\text { number }\end{array}$ & $\delta_{C}$ & $\delta_{\mathrm{H}}, J(\mathrm{~Hz})$ & HMBC & $\cos Y$ \\
\hline $\mathrm{C}-1\left(\mathrm{CH}_{2}\right)$ & 47.9 & $1.05(2 \mathrm{H}, \mathrm{t}, 11.5,23.0)$ & & \\
\hline $\mathrm{C}-2(\mathrm{CHOH})$ & 65.5 & $3.97(1 \mathrm{H}, \mathrm{m})$ & & \\
\hline $\mathrm{C}-3\left(\mathrm{CH}_{2}\right)$ & 44.6 & $1.41(2 \mathrm{H}, \mathrm{d}, 11.5)$ & & \\
\hline C-4 (C) & 39.4 & & & \\
\hline $\mathrm{C}-5(\mathrm{CH})$ & 47.5 & $1.47(1 \mathrm{H}, \mathrm{dd}, 2.5,12.5)$ & & \\
\hline $\mathrm{C}-6\left(\mathrm{CH}_{2}\right)$ & 23.5 & $1.63(2 \mathrm{H}, \mathrm{m})$ & & \\
\hline $\mathrm{C}-7\left(\mathrm{CH}_{2}\right)$ & 37.5 & $2.03(2 \mathrm{H}, \mathrm{m})$ & & \\
\hline C-8 (C) & 147.4 & & & \\
\hline $\mathrm{C}-9(\mathrm{CH})$ & 56.8 & $1.88(1 \mathrm{H}, \mathrm{d}, 10.5)$ & & \\
\hline$C-10(C)$ & 40.7 & & & \\
\hline \multirow[t]{2}{*}{$\mathrm{C}-11\left(\mathrm{CH}_{2}\right)$} & 23.2 & $2.38(1 \mathrm{H}, \mathrm{m})$ & & $\mathrm{H}-11 \mathrm{~b}$ \\
\hline & & $2.37(1 \mathrm{H}, \mathrm{m})$ & & $\mathrm{H}-11 \mathrm{a}$ \\
\hline $\mathrm{C}-12(\mathrm{CH})$ & 133.4 & $5.40(1 \mathrm{H}, \mathrm{t}, 6.0,12.5)$ & $\begin{array}{l}\text { C-9, C-11, } \\
\text { C-14, C-16 }\end{array}$ & \\
\hline$C-13(C)$ & 133.6 & & & \\
\hline $\mathrm{C}-14(\mathrm{CH})$ & 141.5 & $6.32(1 \mathrm{H}, \mathrm{dd}, 10.5,17.5)$ & $C-13, C-16$ & \\
\hline \multirow[t]{2}{*}{$\mathrm{C}-15\left(\mathrm{CH}_{2}\right)$} & 110.0 & $5.05(1 \mathrm{H}, \mathrm{d}, 17.5)$ & $C-13, C-14$ & $\mathrm{H}-14$ \\
\hline & & $4.88(1 \mathrm{H}, \mathrm{d}, 11.0)$ & & $\mathrm{H}-14$ \\
\hline $\mathrm{C}-16\left(\mathrm{CH}_{3}\right)$ & 11.8 & $1.75(3 \mathrm{H}, \mathrm{s})$ & & \\
\hline \multirow[t]{2}{*}{$\mathrm{C}-17\left(\mathrm{CH}_{2}\right)$} & 108.5 & $4.86(1 \mathrm{H}, \mathrm{d}, 1.5)$ & $C-7, C-9$ & $\mathrm{H}-17 \mathrm{~b}$ \\
\hline & & $4.49(1 \mathrm{H}, \mathrm{d}, 1.0)$ & & $\mathrm{H}-17 \mathrm{a}$ \\
\hline \multirow[t]{2}{*}{$\mathrm{C}-18\left(\mathrm{CH}_{2} \mathrm{OH}\right)$} & 71.5 & $3.42(1 \mathrm{H}, \mathrm{d}, 11.0)$ & $\begin{array}{l}\text { C-3, C-4, } \\
\text { C-5, C-19, }\end{array}$ & $\mathrm{H}-18 \mathrm{~b}$ \\
\hline & & $3.18(1 \mathrm{H}, \mathrm{d}, 11.0)$ & & $\mathrm{H}-18 \mathrm{a}$ \\
\hline $\mathrm{C}-19\left(\mathrm{CH}_{3}\right)$ & 18.5 & $0.80(3 \mathrm{H}, \mathrm{s})$ & & \\
\hline $\mathrm{C}-20\left(\mathrm{CH}_{3}\right)$ & 15.8 & $0.81(3 \mathrm{H}, \mathrm{s})$ & & \\
\hline
\end{tabular}

by quantifying the amount of a formazan product metabolized by viable cells from 3-(4,5-dimethylthiazol-2yl)-2,5-diphenyltetrazolium bromide (MTT) solution (Sigma, MO, USA) as previously reported [27]. TZM-bl cells were maintained in complete Dulbecco's Modified Eagle Medium (DMEM; Sigma, MO, USA); containing antibiotics and foetal bovine serum. Cells were plated in 96 well plates (Corning Incorporated, Corning, USA) at $1 \times$ $10^{4}$ cells per well and were treated with crude extract at final concentrations of 100, 50, 25, 12.5, 6.25 and $3.125 \mu \mathrm{g} / \mathrm{mL}$. In the case of the compound, the final concentrations were $3.125-100 \mu \mathrm{M}$. Viability was determined after $72 \mathrm{~h}$ incubation $\left(37^{\circ} \mathrm{C}, 90 \%\right.$ humidity, $5 \% \mathrm{CO}_{2}$ ). Control wells included a negative control (cells and medium only), blank control for the extract (extract and medium only), a toxicity control auranofin; a known toxic compound with antitumour activity [28], and a DMSO control (percentage of DMSO similar to extracts in cells to ensure that this solvent did not cause cell death). The plates were read at $550 \mathrm{~nm}$ using a microtiter plate reader (Multiskan
Ascent; Thermo Labsystems; MA, USA), a reference wavelength of $690 \mathrm{~nm}$ was used and the percentage viability was calculated relative to untreated control cells. Fifty percent cytotoxic concentration $\left(\mathrm{CC}_{50}\right)$ of the extract and compound was obtained using Graphpad Prism (Graphpad Software Inc. CA, USA). This was computed as the concentration of the extract/compound that reduced cell viability by $50 \%$ when compared to controls.

\section{Viability of PBMCs using MTS}

Ethical approval for obtaining blood samples from consenting donors was granted by the Faculties of Natural and Agricultural Sciences and Health Sciences Ethics Committees (EC080506-019; 163/2008, University of Pretoria, South Africa). Freshly isolated healthy peripheral blood mononuclear cells (PBMCs) were suspended in complete RPMI 1640 (Sigma, MO, USA) medium (containing antibiotics and foetal bovine serum). Cells were then stimulated with phytohemagglutinin-protein (PHA-P, $4 \mu \mathrm{g} / \mathrm{mL}$ ), plated in 96 well plates (Corning Incorporated, Corning, USA) at $1 \times 10^{5}$ cells per well and treated with the extract and compound at final concentrations of 100, 50, 25, 12.5, 6.25 and $3.125 \mu \mathrm{g} / \mathrm{mL}$. The number of viable cells was detected after $72 \mathrm{~h}$ using 3-(4,5-dimethylthiazol-2-yl)-5-(3carboxymethoxyphenyl)-2-(4-sulfophenyl)-2H-tetrazolium, inner salt (MTS) solution (Promega Corporation, WI, USA). Control wells included a toxicity control auranofin and the plates were read at $492 \mathrm{~nm}$ (reference wavelength of $690 \mathrm{~nm}$ ). The percentage viability was calculated relative to an untreated control of cells only and the $\mathrm{CC}_{50}$ values were determined using Graphpad Prism (Graphpad Software Inc. CA, USA).

\section{Real time cell analysis}

Confirmatory cytotoxicity analysis for the crude extract and isolated compound was performed using a real time cell electronic sensing (RT-CES) device, xCELLigence (Roche Diagnostics, MA, Germany) to monitor proliferation of the TZM-bl cells in the presence of the extract and isolated compound. A detailed procedure was followed as previously described [29]. The xCELLigence system monitors cellular events in real time without the incorporation of labels by measuring electrical impedance across interdigitated gold micro-electrodes integrated on the bottom of special tissue culture plates. Increasing attachment of cells to the electrodes increases electrode impedance which is displayed as cell index (CI) $[30,31]$. Cell titration was carried out as recommended by the manufacturer in order to determine an optimal cell number that reaches an index of \pm 1 after $24 \mathrm{~h}$, before treatment with the samples. Each well was seeded with 10,000 cells, which was the ideal cell number obtained from the titration. The $\mathrm{CC}_{50}$ of $\mathrm{O}$. labiatum extract obtained with an MTT assay was tested alongside $10 \mu \mathrm{M}$ 
auranofin as a positive control for toxicity. Untreated cells were also included as controls. Cells were first allowed to adhere for $24 \mathrm{~h}$ before treating them with extracts. The cellular effects of the extracts were monitored for $72 \mathrm{~h}$ and $\mathrm{CI}$ values were recorded. The compound was applied in the same manner. One concentration of the compound, 112.6 $\mu \mathrm{M}, \mathrm{CC}_{50}$ determined with MTT was also monitored for its effect in real time for $72 \mathrm{~h}$.

\section{Antioxidant assays}

The antioxidant potential of the extract and terpene were investigated using four different antioxidant assays since antioxidant mechanisms could include different reactions with radical species. For these assays, all reagents were obtained from Sigma Aldrich (Missouri USA) unless stated otherwise. Ascorbic acid was used as the positive control for all these assays at concentrations ranging from $(0.078 \mu \mathrm{g} / \mathrm{mL}$ to $100 \mu \mathrm{g} / \mathrm{mL})$.

\section{DPPH antioxidant assay}

The potential antioxidant activity of $O$. labiatum extract and Labda-8(17),12E,14-triene-2R,18-diol was assessed on the basis of the scavenging ability of the test samples towards a stable 2,2-diphenyl-1-picrylhydrazyl (DPPH) free radical. Test samples were prepared at a starting concentration of $100 \mu \mathrm{g} / \mathrm{mL}$ after mixing with $90 \mu \mathrm{M}$ $\mathrm{DPPH}$ ethanol solution. A series of concentrations were tested for the samples in order to determine the 50\% inhibitory concentration $\left(\mathrm{IC}_{50}\right)$. Samples were incubated with DPPH in the dark for $30 \mathrm{~min}$ at room temperature. Absorbance values were measured at $550 \mathrm{~nm}$ (Multiskan Ascent; Thermo Labsystems; MA, USA) and converted into percentage of antioxidant activity [32]. Background control was samples in ethanol only and a DPPH only control was also include. $\mathrm{IC}_{50}$ was determined using Graphpad Prism (Graphpad Software Inc. CA, USA). The percentage inhibition was calculated by using the formula:

$$
\begin{aligned}
100-[ & (\text { Sample Optical density }(O D) \\
& - \text { Sample background OD }) /(D P P H \text { only } O D) \times 100]
\end{aligned}
$$

\section{Ferric reducing antioxidant power (FRAP)}

The FRAP assay was performed a previously described, with minor modifications [33,34]. The terpenoid compound and extract $(0.781$ to $100 \mu \mathrm{g} / \mathrm{mL})$ was dissolved in DMSO (5\%) and further diluted with double distilled deionized water.

Freshly prepared FRAP reagent $(20 \mathrm{~mL}$ acetate buffer, $2 \mathrm{~mL}$ TPTZ solution, $2 \mathrm{~mL}$ ferric chloride solution and $2.4 \mathrm{~mL}$ autoclaved $\mathrm{dH}_{2} \mathrm{O}$ ) was heated to $37^{\circ} \mathrm{C}$. A reagent blank, ascorbic acid calibrations $(0.078 \mu \mathrm{g} / \mathrm{mL}$ to $10 \mu \mathrm{g} / \mathrm{mL})$ and samples were submitted to the FRAP assay as follows: $8 \mu \mathrm{l}$ of sample and $240 \mu \mathrm{l}$ FRAP reagent were added to 96 well plates, mixed and incubated for 10 minute. Absorbance readings were obtained at $595 \mathrm{~nm}$ and plotted as (Sample Optical density (OD) - Sample background ODblank) against compound or extract concentration.

\section{Cupric reducing antioxidant capacity (CUPRAC)}

This assay was performed as previously described [35]. The terpenoid compounds and extract concentrations ranged from $0.781 \mu \mathrm{g} / \mathrm{mL}$ to $100 \mu \mathrm{g} / \mathrm{mL}$ and that for ascorbic acid ranged from $0.078 \mu \mathrm{g} / \mathrm{mL}$ to $10 \mu \mathrm{g} / \mathrm{mL}$. The sample $(50 \mu \mathrm{l})$ and $150 \mu \mathrm{l}$ CUPRAC reagent consisting of $10 \mathrm{mM}$ Copper(II)chloride, $7.5 \mathrm{mM}$ neucoproine (AEC Amersham) and ammonium acetate buffer (1\% (v/v) acetic acid, 0.1 M ammonium acetate, $\mathrm{pH}$ ) were mixed and incubated for 30 minutes at room temperature before absorbance readings were obtained at $450 \mathrm{~nm}$. An experiment blank and sample background controls were also included. The data was plotted as (Sample Optical density (OD) - Sample background OD-blank) against compound or extract concentration.

\section{Crocin bleaching assay using 2,2'-azobis (2-amidonopropane) hydrochloride (AAPH)}

Reagents: PBS (27 mM KCl, $18 \mathrm{mM} \mathrm{KH}_{2} \mathrm{PO}_{4}, 1.4 \mathrm{M} \mathrm{NaCl}$, $0.1 \mathrm{M} \mathrm{Na}_{2} \mathrm{HPO}_{4}$ and autoclaved $\left.\mathrm{dH}_{2} \mathrm{O}\right), 20 \mu \mathrm{M}$ crocin solution (crocin dissolved in 30\% methanol), AAPH solution (5 mg/mL AAPH dissolved in 1x PBS).

This assay was performed according to a previously described method [36]. Fifty microliters of the terpenoid compound and extract $(0.78 \mu \mathrm{g} / \mathrm{mL}$ to $100 \mu \mathrm{g} / \mathrm{mL})$ and ascorbic acid $(0.078 \mu \mathrm{g} / \mathrm{mL}$ to $10 \mu \mathrm{g} / \mathrm{mL})$ were added to $100 \mu \mathrm{l}$ crocin solution and $100 \mu \mathrm{l}$ of AAPH solution. These were mixed and incubated for 1 hour at room temperature before absorbance readings were obtained at $450 \mathrm{~nm}$. The absorbance readings were plotted as (Sample Optical density (OD) - Sample background ODblank) against compound or extract concentration.

\section{Cytokine quantitation using cytometric bead array (CBA)}

Ethical approval for obtaining blood samples from consenting donors was granted by the Faculties of Natural and Agricultural Sciences and Health Sciences Ethics Committees (EC080506-019; 163/2008, University of Pretoria, South Africa). Sample preparation: Blood samples were taken from healthy volunteers; 9 individuals for extract and 14 for compound. Freshly isolated PBMCs stimulated with PHA-P $(4 \mu \mathrm{g} / \mathrm{mL})$, were seeded at $1 \times 10^{6}$ cells/well in order to get enough cytokine produced for quantitative detection. Incubation of the cells with noncytotoxic concentrations of the extract $(25 \mu \mathrm{g} / \mathrm{mL})$ and compound $(50 \mu \mathrm{M})$ was done for $24 \mathrm{~h}$. The supernatant was collected and stored at $-20^{\circ} \mathrm{C}$ until testing.

Quantitation: Cytokine levels were analysed in the tissue culture supernatant using a BD CBA human Th1/ 
Th2/Th17 cytokine kit (BD Biosciences, CA, USA). The CBA kit simultaneously measured IL-2, IL-4, IL-6, IL-10, TNF, interferon gamma (INF- $\gamma$ ) and IL-17A protein levels in a single sample using a FACSArray Bioanalyzer (BD Biosciences, CA, USA). The assay was performed according to the manufacturer's instructions. Briefly, the supernatant was thawed and $50 \mu \mathrm{l}$ of each sample was mixed with the cytokine capture beads and the detector reagent, phycoerythrin (PE)-conjugated detection antibodies, to form sandwich complexes. The intensity of PE fluorescence of each sandwich complex reveals the concentration of that cytokine [25]. The limits of detection for each cytokine was as follow: $2.6 \mathrm{pg} / \mathrm{mL}$ for IL-2, $4.9 \mathrm{pg} / \mathrm{mL}$ for IL-4, $2.4 \mathrm{pg} / \mathrm{mL}$ for IL-6, $4.5 \mathrm{pg} / \mathrm{mL}$ for IL-10, $3.8 \mathrm{pg} / \mathrm{mL}$ for TNF, $3.7 \mathrm{pg} / \mathrm{mL}$ for IFN- $\gamma$ and $18.9 \mathrm{pg} / \mathrm{mL}$ for IL-17A.

\section{AP-1 (c-Jun) inhibition studies}

The AP-1 group of transcription factors binds to the enhancer/promoter region of various cytokine genes in activated cells [37]. The extract and isolated compound were also evaluated to determine inhibition of the c-Jun component of AP-1 as an indication of prevention of transcription of inflammatory genes [22]. The Abcam c-Jun (Ps73) ELISA kit (Abcam ${ }^{\circ}$, Cambridge, UK) was used in the detection of PHA-P induced AP-1 from PBMCs and the assay performed according to the manufacturer's protocol. PBMCs $\left(1 \times 10^{6}\right.$ cells $\left./ \mathrm{mL}\right)$ pretreated with or without the extract and diterpenoid compound were collected and washed with phosphate buffered saline. The cells were then lysed and antibody mix was added and incubated for $1 \mathrm{~h}$ in a microplate. The microplate was washed before the substrate was added for colour development. A stop solution was added to stop the reaction after $10 \mathrm{~min}$ and the fluorescence signal obtained at 544/590 nm using a Fluoroskan Ascent ${ }^{\circ}$ plate reader (Labsystems, Helsinki, Finland).

\section{Nitrite and nitrate detection by colorimetric assay}

The effect of extract and isolated compound on NO production was studied using an NO assay colorimetric kit (Calbiochem, CA, USA). In aqueous solution, NO is rapidly converted to nitrate and nitrite. Hence, for accurate determination of the total NO generated, both nitrate and nitrite levels must be monitored. Spectrophotometric quantitation of nitrite using only the Griess reagent does not measure nitrate. Therefore, the NADH-dependent enzyme nitrate reductase is used to convert the nitrate to nitrite prior to quantitation using the Griess reagent. NO was measured from PBMCs by plating cells in 96 well plates at $2.0 \times 10^{5}$ cells/well. Cells were pre-incubated for $1 \mathrm{~h}$ with non-cytotoxic concentrations of the crude extract $(25 \mu \mathrm{g} / \mathrm{mL})$ and labdane diterpenoid (50, 25 and $10 \mu \mathrm{M})$ before stimulating for $\mathrm{NO}$ with a non-cytotoxic concentration of PHA-P, $25 \mu \mathrm{g} / \mathrm{mL}$ and further incubating for
$24 \mathrm{~h}$. After the $24 \mathrm{~h}$ incubation, cell culture supernatant $(50 \mu \mathrm{l})$ was collected and incubated with $1 \mathrm{U} / \mu \mathrm{l}$ of nitrate reductase in the presence of $0.2 \mathrm{mM} \mathrm{NADH}$ and $50 \mathrm{mM}$ MOPS buffer, pH 7.0. After $20 \mathrm{~min}$, Griess reagent was added and further incubated for $5 \mathrm{~min}$ at room temperature. The colour was read at $550 \mathrm{~nm}$ (Multiskan Ascent; Thermo Labsystems; MA, USA). A standard curve was generated, using freshly prepared $0-100 \mu \mathrm{M}$ potassium nitrate dissolved in assay buffer, to quantitate unknown nitrite in samples.

\section{Statistical analysis}

Data for all experiments is presented as the mean \pm standard deviation $(n=3-6)$. Since cytokine profiles vary from person to person, the cytokine concentrations obtained for each individual were $\log$ transformed in order to standardize the data and make it more comparable [25,38]. Significant differences were estimated using Graphpad Prism 5 (Graphpad Software Inc. CA, USA) and Student's $t$ test for unpaired observations. A p $<0.05$ was considered significant.

\section{Results \\ Cytotoxicity}

The $\mathrm{CC}_{50}$ of crude O. labiatum extract was $62.6 \pm 0.6$ $\mu \mathrm{g} / \mathrm{mL}$ for TZM-bl cells and $30.1 \pm 0.4 \mu \mathrm{g} / \mathrm{mL}$ in PBMCs determined by viability dye MTT and MTS respectively. The PBMCs $\left(1 \times 10^{5}\right.$ cells/well $)$ used in this study did not adequately metabolize the viability dye MTT but properly metabolized MTS which is why the latter dye was used in the PBMC analyses and MTT for TZM-bl assessments. Tetrazolium dyes are metabolized differently by different cell types. Considerable evidence indicates that the reduction of MTS occurs at the cell surface or at the level of the plasma membrane via trans-plasma membrane electron transport and not inside a cell as is the case with MTT [39]. It is therefore possible that MTT was unable to properly penetrate the membrane of PBMCs for proper intracellular metabolism and MTS which is metabolized on the cell-surface was easily metabolized by these mononuclear cells.

Cytotoxicity of the crude extract was confirmed with RT-CES. RT-CES monitored the effect of the extract on cell viability (Figure $2 \mathrm{~A}$ ), in real-time and confirmed the $\mathrm{CC}_{50}$ value obtained with MTT. At $72 \mathrm{~h}$ post treatment, the cell index for untreated cells (i) was 2.5. Cells treated with $62.6 \pm 0.6 \mu \mathrm{g} / \mathrm{mL}$ crude extract $\left(\mathrm{CC}_{50}\right)$ resulted in sample uptake (dip in cell growth before $24 \mathrm{~h}$ ) and metabolisation (hump) as demonstrated by the pattern (ii) in Figure 2A. When the extract was properly metabolized, a reduction in cell viability was observed. About $50 \%$ (half of cell index value of control cells) of treated cells remained viable at 72 hours of incubation. 


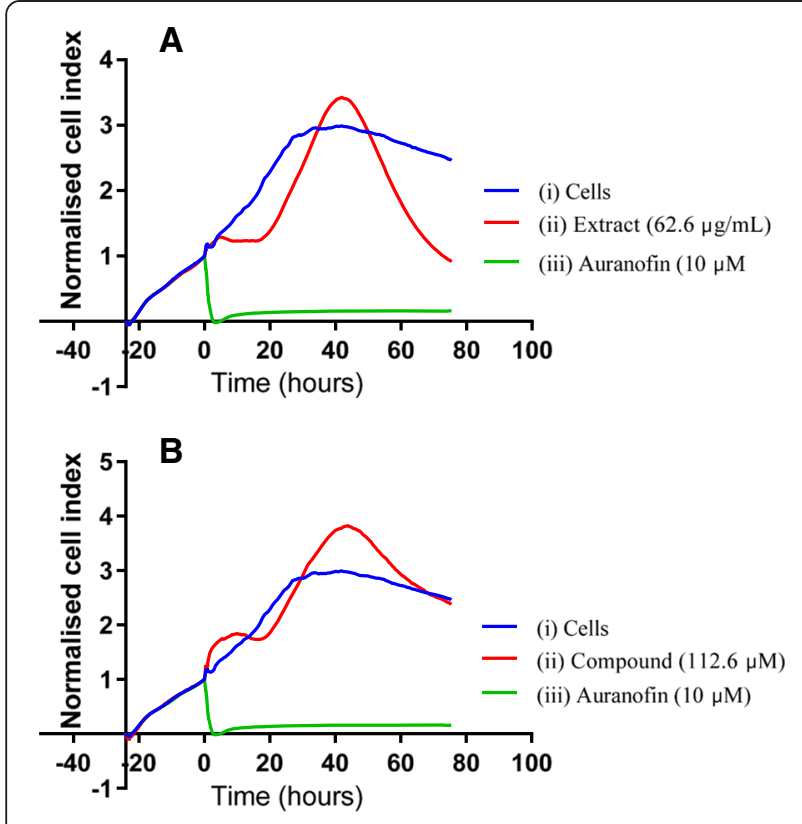

Figure 2 Real time monitoring of $O$. labiatum effect on the viability of TZM-bl cells. Cells were exposed to $62.6 \mu \mathrm{g} / \mathrm{mL}$ of extract $(\mathbf{A})$ and $112.6 \mu \mathrm{M}$ compound (B), which were the $\mathrm{CC}_{50}$ values determined in a tetrazolium dye assay. Auranofin (iii) was used as a positive control for toxicity and caused cell death almost from the time of addition until end of incubation period (72 h). A unique growth pattern was observed in extract treated cells with uptake in the first 48 hours followed by extract content being metabolized by the cells resulting in an increase in cell index above that of untreated cells which following prolonged exposure is reduced to half cell index of control cells (i) at $72 \mathrm{~h}$. RT-CES demonstrated low cytotoxicity for compound treated cells $72 \mathrm{~h}$ similar to that of untreated cells (i). For the compounds, uptake and metabolism was similar to that of extract however, elevated cell indices was maintained. Data was normalized against the time point before extract addition.

The cytotoxicity of the labdane diterpenoid compound, Labda-8(17),12E,14-triene-2R,18-diol, was also studied using viability dyes MTT and MTS and it was found to cause $\mathrm{CC}_{50} \mathrm{~s}$ of $112.6(34.3 \mu \mathrm{g} / \mathrm{mL}) \pm 0.2$ and $70(21.3$ $\mu \mathrm{g} / \mathrm{mL}) \pm 0.4 \mu \mathrm{M}$ in TZM-bl and PBMCs respectively. The cytotoxicity results were again confirmed with RT-CES and these results are depicted in Figure 2B. Extract uptake was observed before $24 \mathrm{~h}$ and metabolization of the sample resulted in a cell index value of 2.5 (ii) equivalent to that of untreated control cells (i) at $72 \mathrm{~h}$. RT-CES results indicated that the $\mathrm{CC}_{50}$ of the compound obtained in TZM-bl cells was not cytotoxic. Since RT-CES does not involve the use of dye uptake or invasive methods to measure cell status, this suggests this technique to be more sensitive and accurate than MTT.

\section{Antioxidant activity}

The antioxidant effect of the test samples and ascorbic acid obtained in the DPPH, FRAP, CUPRAC and crocin bleaching antioxidant assays are shown in Figure 3. For all the assays, a dose dependent antioxidant activity was observed for the extract with $\mathrm{IC}_{50}$ values of $13 \pm 0.8$ $\mu \mathrm{g} / \mathrm{mL}, 53.62 \pm 0.57,47.32 \pm 0.76 \mu \mathrm{g} / \mathrm{mL}$ and $54.86 \pm 1.28$ $\mu \mathrm{g} / \mathrm{mL}$ respectively. The $\mathrm{IC}_{50}$ of ascorbic acid for the individual assays was found to be $1.1 \pm 0.03,4.74 \pm 0.60$, $5.29 \pm 0.03$ and $6.69 \pm 0.004 \mu \mathrm{g} / \mathrm{mL}$ respectively. For all the assays, the labdane diterpenoid compound demonstrated minimal to no antioxidant activity $(<50 \%)$ for all tested concentrations. Each assay was performed at least 5 times.

\section{Effect of 0 . labiatum on cytokine production}

Using the Cytometric Bead Array (CBA) human Th1/ Th2/Th17 cytokine kit (BD Biosciences, CA, USA), 7 cytokines, IL-2, IL-4, IL-6, IL-10, TNF, INF- $\gamma$ and IL-17A, were analysed and quantified (Figure 4) following exposure of PBMCs to plant material. O. labiatum crude extract was tested for anti-inflammatory properties at 25 $\mu \mathrm{g} / \mathrm{mL}$, a non-cytotoxic concentration. Cytokine production in untreated PBMCs was used as a control for comparison to the production of cytokines in extract treated PBMCs. The extract significantly $(\mathrm{p}<0.05)$ decreased the production of pro-inflammatory cytokines IL-2, IL-4, IL-6 and IL-17A (Figure 4). For IL-10, INF- $\mathrm{\gamma}$ and TNF, there was no significant $(\mathrm{p}>0.05)$ difference detected in untreated and extracted treated samples even though production of those cytokines was lowered by the extract.

\section{Effect of labda-8(17),12E,14-triene-2R,18-diol on pro-inflammatory cytokines}

The anti-inflammatory property of the purified labdane diterpenoid was also studied using the CBA human Th1/Th2/Th17 cytokine kit (BD Biosciences, CA, USA). The compound was tested at $50 \mu \mathrm{M}$, a non-toxic concentration. The results obtained were compared to untreated cells. The compound was found to significantly $(\mathrm{p}<0.05)$ inhibit the production of all cytokines tested except for IL-6 as illustrated in Figure 5. The production of IL-6, which acts as both an anti- and pro-inflammatory cytokine, was significantly $(\mathrm{p}<0.05)$ up-regulated.

\section{AP-1 inhibition by the labdane diterpenoid}

The effect of the terpenoid $(50 \mu \mathrm{M}, 25 \mu \mathrm{M} \& 10 \mu \mathrm{M})$ and the extract $(25 \mu \mathrm{g} / \mathrm{mL} \& 10 \mu \mathrm{g} / \mathrm{mL})$ from the plant, O. labiatum were tested for activity against c-Jun component of AP-1 $(n=3)$ in PHA stimulated PBMCs. The isolated compound significantly inhibited $(\mathrm{p}<0.05)$ AP1 at $50 \mu \mathrm{M}$, but not at lower concentrations (Figure 6). $\mathrm{N}$-acetyl cysteine (NAC) which was used as the positive control significantly inhibited AP-1 ( $\mathrm{p}<0.005)$. When cells were co-treated with the terpenoid compound and NAC, AP-1 was significantly stimulated $(\mathrm{p}<0.05)$ at $50 \mu \mathrm{M}$, but not at lower concentrations suggesting that 


\section{A}
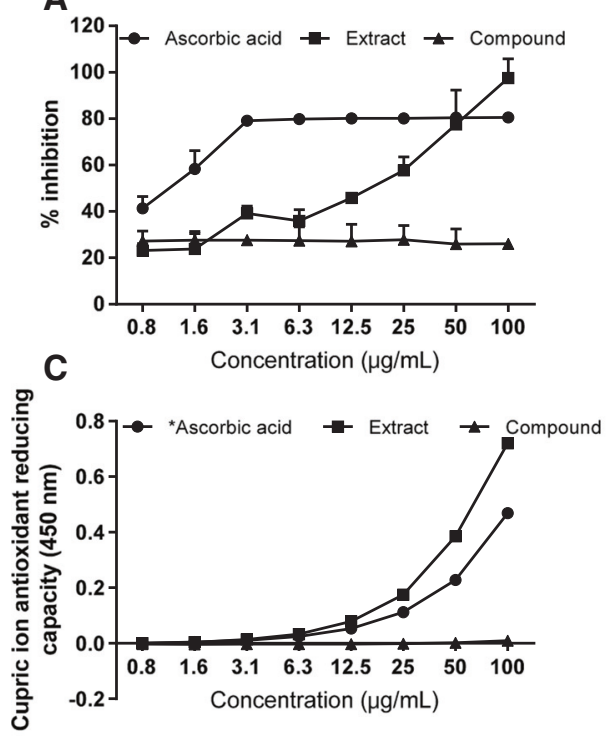

B
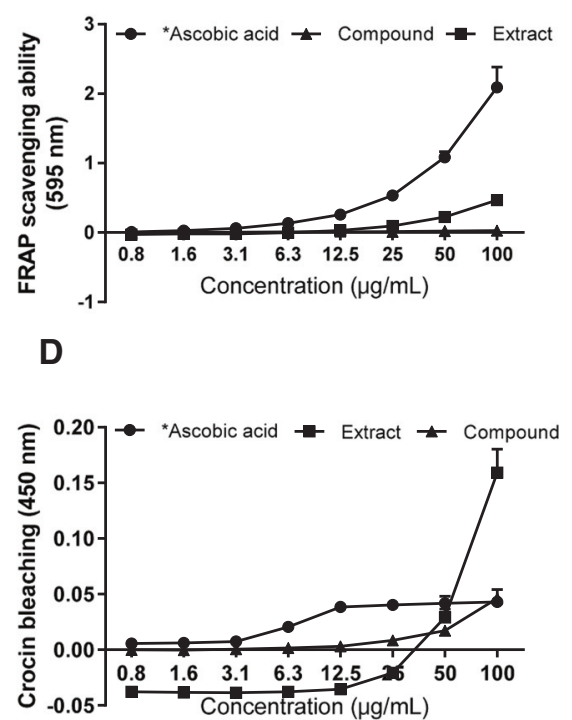

Figure 3 Antioxidant effect of the $\boldsymbol{O}$. labiatum extract (squares) and the isolated compound (triangles). The DPPH free radical scavenging, the FRAP, cupric ion reducing activity, and crocin bleaching effect are shown in $\mathbf{A}, \mathbf{B}, \mathbf{C}$ and $\mathbf{D}$ respectively $(n=5-6$ ). The DPPH data is shown as percentage inhibition. The $\mathrm{IC}_{50 \text { s }}$ for the extract were $13 \pm 0.8 \mu \mathrm{g} / \mathrm{mL}, 53.62 \pm 0.57,47.32 \pm 0.76 \mu \mathrm{g} / \mathrm{mL}$ and $54.86 \pm 1.28 \mu \mathrm{g} / \mathrm{mL}$ respectively. Ascorbic acid was used as positive control. The extract exhibited strong antioxidant activity while the diterpenoid compound did not. ${ }^{*}$ tested in two fold serial dilutions from $0.08-10 \mu \mathrm{g} / \mathrm{mL}$.

the anti-inflammatory activity of the terpenoid was as a result of inhibition of the AP-1 pathway. Cells treated with extract alone, as well as co-treated with extract and NAC significantly $(\mathrm{p}<0.05)$ stimulated AP-1 production (Figure 6).

The effect of the compound on NF-kB from nuclear extracts obtained from PBMCs was assessed using the NF-kB (p65) transcription factor assay kit (Rockland

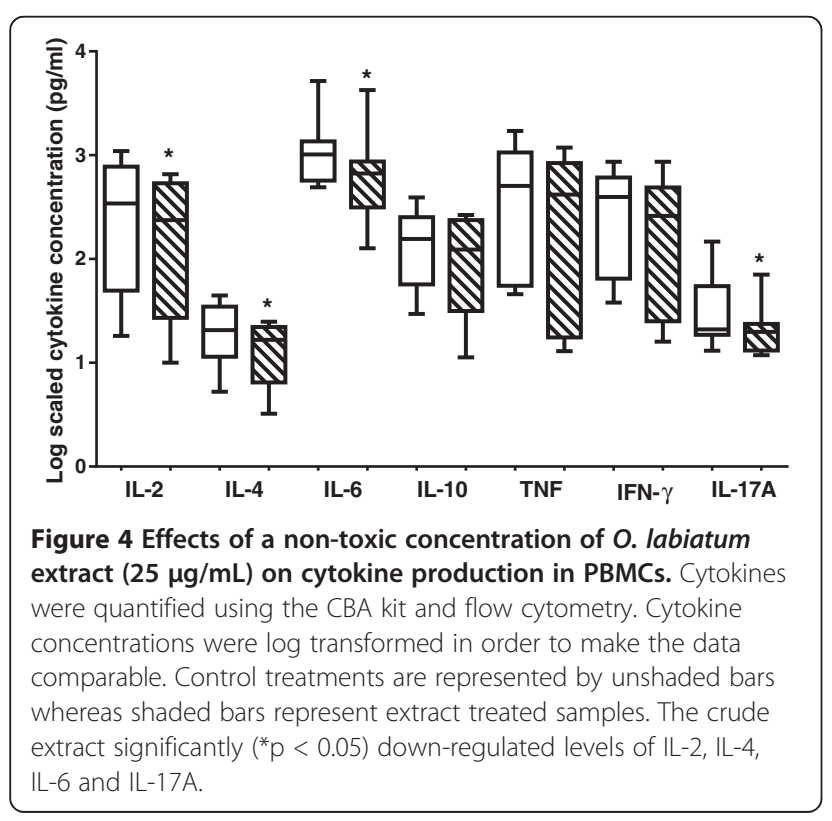

Immunochemicals, Gilbertsville, PA, USA). The compound had no appreciable effect on NF-kB at tested concentrations (data not shown).

\section{NO levels in culture supernatant reduced by $O$. labiatum and labdane diterpenoid}

The effects of the extract and compound on PHAinduced NO production in PBMCs were investigated by quantitating nitrite in culture medium using the Griess reaction. Unstimulated control cells, after $24 \mathrm{~h}$ of incubation, produced a negligible amount of $\mathrm{NO}(<10 \mu \mathrm{M})$. NO production in PHA stimulated cells was evident $(43 \mu \mathrm{M})$, while no significant levels of NO were detected in the extract treated cells as illustrated in Figure 7. The three concentrations tested for the labdane diterpenoid compound significantly $(\mathrm{p}<0.05)$ decreased the level of $\mathrm{NO}$ in the cells with $25 \mu \mathrm{M}$ of the compound being more significant by reducing NO production to an undetectable level (Figure 7).

\section{Discussion}

The data obtained in this study suggest that $O$. labiatum has immune supportive activities in addition to direct antioxidant abilities. RT-CES proved to be a more sensitive technique for detecting the effect of treatment on cell viability. The technique detected a unique cell growth pattern with extract and compound uptake and metabolism which would not have been observed with viability dyes. The use of conventional methods such as MTT or 


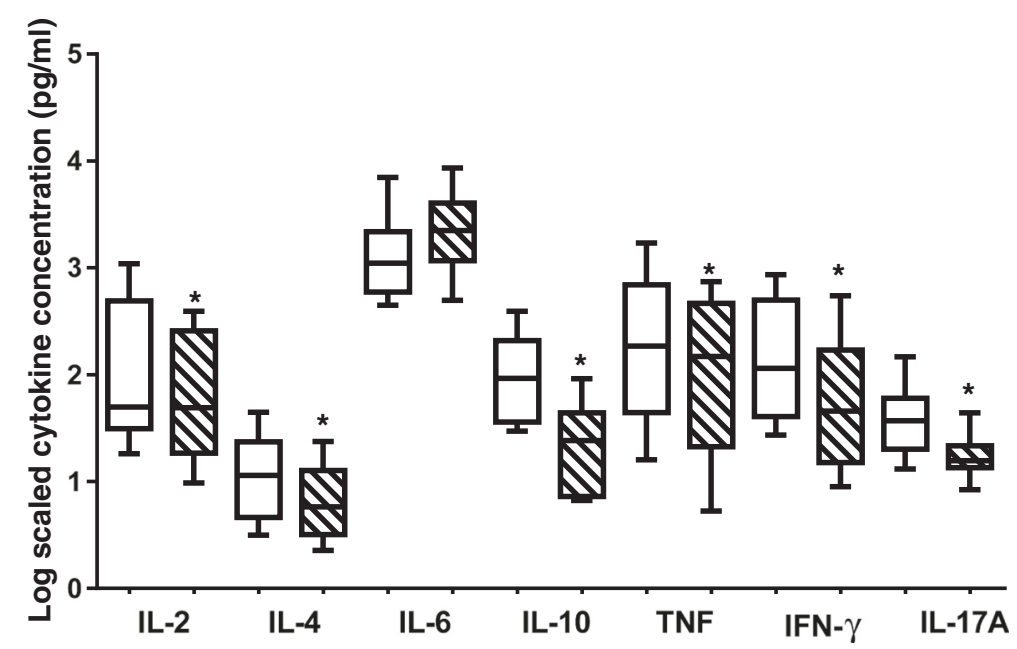

Figure 5 Influence of labda-8(17),12E,14-triene-2R,18-diol on cytokine production in PBMCs as quantitated by CBA analysis and flow cytometry. Cells were treated with a non-toxic concentration of $50 \mu \mathrm{M}$. Concentrations obtained of tested cytokines were log transformed in order to make the data comparable. Control treatments are unshaded whereas compound treated cells are shaded. IL- 6 was the only cytokine that was up-regulated by the compound. The rest of the cytokines were significantly $\left.{ }^{*} p<0.05\right)$ down-regulated.

MTS has been reported to be insufficient if used alone since these methods only produce end-point data [40]. RT-CES, which is label-free, is able to capture important effects such as the onset and rate of cytotoxicity as well as other proliferation dynamics such as cytostasis [29]. Sensitivity and accurate reflection using RT-CES has been attributed to the ability of the technique to reflect on the cell concentration and changes in cell morphology more than viability dyes [40].

O. labiatum extract exhibited strong antioxidant activity while the isolated labdane diterpenoid, Labda-8(17),12E, 14-triene-2R,18-diol, was not a good antioxidant suggesting the antioxidant ability of the crude extract to be due to the presence of other compound(s). Non-terpenoid compounds present in the extract such as flavonoids are more likely to be responsible for antioxidant activity of plant extracts. Flavonoids, vitamins and polyphenols present in plants are known to be powerful antioxidants [41].

The bead array technology used in this study allowed for simultaneous detection of multiple cytokines in a single sample. Because cytokines influence one another, an imbalance in especially Th1 and Th2 cytokines can lead to the pathogenesis of acute and chronic inflammatory diseases [23]. Therefore, in studies where cytokines are investigated as prognostic indicators [25], for therapeutic uses [42] or to assess their modulation by potential

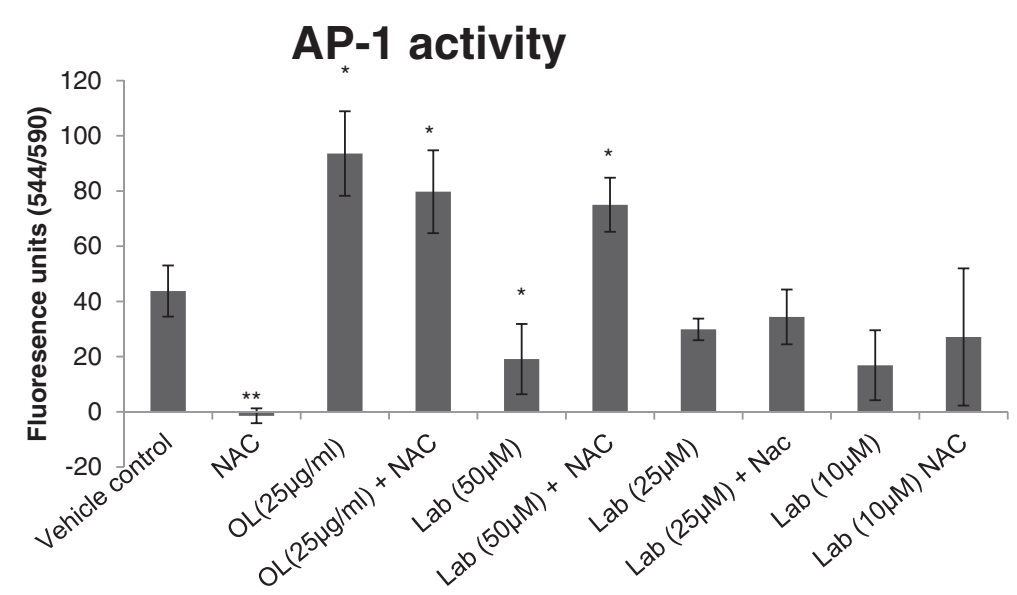

Figure 6 The effect of the isolated compound and plant extract on AP-1. The isolated labdane diterpenoid (Lab) and the extract (OL) were tested for activity against the $c-J u n$ component of AP-1 $(n=3)$ in PHA stimulated PBMCs. Lab significantly ( $p<0.05)$ inhibited AP-1 in PBMCs at $50 \mu \mathrm{M}$. NAC (100 $\mathrm{gg} / \mathrm{mL})$ was used as positive control and significantly inhibited AP-1 (a). Co-treatment with NAC resulted in stimulation of AP-1 production. At $25 \mu \mathrm{g} / \mathrm{mL}$, the plant extract significantly stimulated AP-1 in PBMCs $(p<0.05)$. 


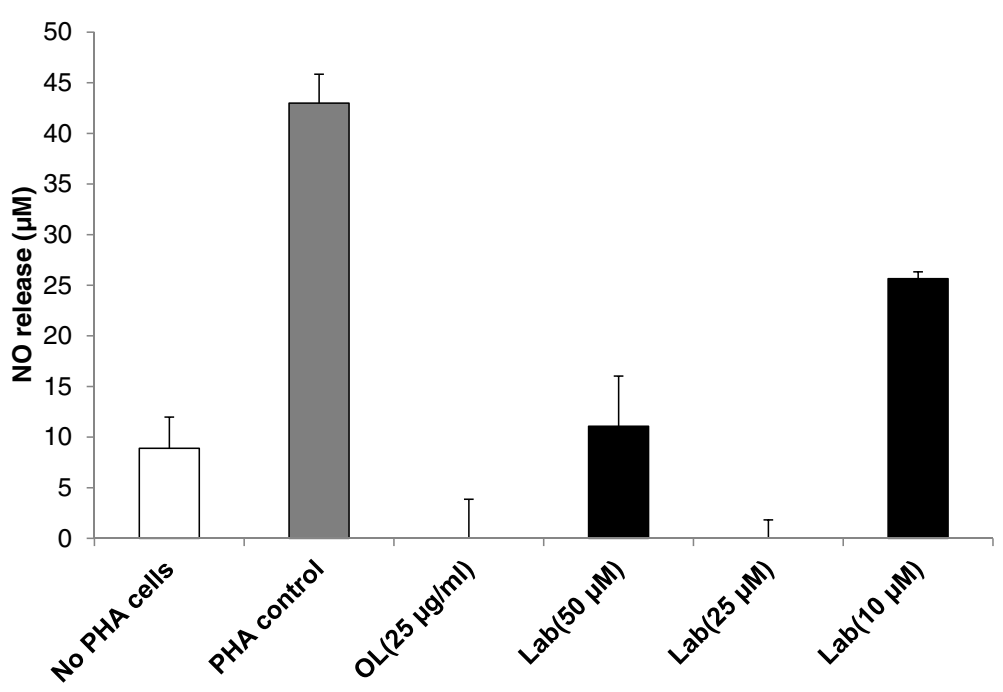

Figure $\mathbf{7}$ Inhibition of NO release by $\mathbf{O}$. Iabiatum extract and labdane diterpenoid. PBMCs were pre-incubated for $1 \mathrm{~h}$ with the indicated concentrations of the extract (OL) and compound (Lab) and then stimulated with $25 \mu \mathrm{g} / \mathrm{mL}$ PHA for $24 \mathrm{~h}$. Untreated cells were used as a control. Nitrite accumulation was measured with the Griess reagent. Extract and compound concentrations used were non-toxic. The results were expressed as mean \pm SD.

drugs [43], it is important to study an array of these molecules representative of all 3 subsets (Th1/Th2/Th17) as was done here.

Lamiaceae terpenoids have been documented to have anti-inflammatory as well as antitumor effects [44]. The isolation of the compound Labda-8(17),12E,14-triene2R,18-diol from O. labiatum was first reported in 2007 [12]. The only investigations done on the labdane diterpenoid by these authors were anti-cancer testing against breast cancer cells and an anti-tuberculosis study in which the compound did not inhibit $M$. tuberculosis activity at the highest concentration tested but showed moderate cytotoxic effects against a breast cancer cell line [12]. According to the literature, some labdane diterpenoid compounds have been shown to possess immune enhancing properties [9] which encouraged the investigation of these specific compounds for anti-inflammatory and/or any immune supportive properties. The ability of the isolated compound to down-regulate pro-inflammatory cytokines, as was demonstrated here, can be of therapeutic importance. The crude extract suppressed IL-2, IL-4, IL-6 and IL-17A while the compound suppressed all cytokines tested except for IL-6 which was up-regulated. IL-6, which can act as a pro- or anti-inflammatory cytokine, is part of a network of cytokines that trigger or regulate immune responses and its increase by the compound in comparison to the inhibitory effect on pro-inflammatory cytokines contributes a beneficial balance to the host $[25,45]$.

IL-2 and IL-17A have been reported to be responsible for activating pathogenic inflammation in a number of inflammatory skin diseases such as psoriasis [46,47]. High levels of IL-17A are reportedly associated with several chronic inflammatory diseases including rheumatoid arthritis and multiple sclerosis $[48,49]$. Therefore, lowering these cytokines in such cases will be of clinical use to the affected individual.

The down-regulation of the following cytokines IL-4, IL-10 and TNF by the extract and compound can be of general therapeutic significance. Over expression of these cytokines has been linked to certain autoimmune diseases as well as activation of pathogenic inflammation $[46,47]$. Inhibiting IL-4 has been associated with alleviating allergies while the neutralization of IL-10 has been linked to the reduction of helminth infection by restoring the function of Th2 effector cells [50].

The production of TNF was drastically inhibited by the labdane diterpenoid compound and this is a proinflammatory cytokine associated with cancers and autoimmune diseases [51]. TNF- $\alpha$ is regarded as a major pro-inflammatory cytokine and there is a continuous search for potential TNF- $\alpha$ inhibitors from natural products due to serious adverse side-effects of existing protein-based inhibitors [26]. Overproduction of TNF- $\alpha$ in rheumatoid arthritis patients has been linked to increased ROS [52]. Inhibiting high levels of this cytokine in such patients should also decrease ROS production and consequently inflammation and cellular damage. TNF- $\alpha$ has also been reported to induce NF- $\alpha \beta$ production [53] and this protein is inhibited by the presence of antioxidants [54]. Here, O. labiatum showed antioxidant activity and the ability to lower the production of TNF- $\alpha$ meaning it could suppress NF- $k \beta$ production, further supporting this plant being potentially useful in diseases with pathogenesis enhanced by NF- $\kappa \beta$. 
Different signalling pathways exist, including NF-kB, AP-1 and MAPK. Inhibition of each pathway can result in lower levels of specific cytokines such as IL-2 being produced due to inflammation [55]. The isolated labdane diterpenoid significantly inhibited c-Jun in the AP-1 pathway at $50 \mu \mathrm{M}$, indicating that inhibition of AP-1 is the mechanism by which the isolated compound exhibited its anti-inflammatory behaviour. The extract significantly stimulated c-Jun in AP-1 suggesting that the presence of other components in the extract could have resulted in a synergistic stimulatory effect on AP-1 production.

The reduction of INF- $\gamma$ by the labdane diterpenoid in this study is suggestive of therapeutic potential. INF- $y$ is reportedly involved in the inflammatory events underlying a vascular inflammatory condition called abdominal aortic aneurysms (AAA) [56]. A large quantity of INF- $\gamma$ was reported [56] in supernatants from AAA explant cultures that suggested this cytokine to be involved in AAA pathogenesis. Regulating the production of INF- $\gamma$ in AAA patients by reducing its production could assist in alleviating that inflammatory condition. Another study [57] reported high production of INF- $\gamma$ in the brain and periphery to be involved in activating certain metabolic pathways which leads to an inflammation cascade that results in aging and aging-associated medical psychiatric disorders. Suppressing INF-y in such cases could be beneficial in avoiding/minimising psychiatric disorders associated with aging.

The anti-inflammatory properties of $O$. labiatum by pro-inflammatory cytokines inhibition were supported by the ability of the extract and labdane diterpenoid to reduce the production of $\mathrm{NO}$ release. NO, which is regarded as a potent inflammatory mediator, was inhibited at concentrations that were not toxic indicating that the NO actions of the extract and compound are not attributable to cytotoxicity. The data presented here confirms the ability of diterpenoids to also possess antiinflammatory abilities through NO inhibition as previously reported [9].

Antioxidation and anti-inflammation properties of plants are routinely investigated and are considered to be among the primary health benefits of natural products. In addition, antioxidative agents prevent the formation of a number of diseases including inflammatory diseases. The anti-inflammatory properties of the $O$. labiatum extract as well as that of the isolated compound strongly suggest the immune enhancing properties of this plant.

\section{Conclusion}

The in vitro data obtained from this study demonstrated for the first time that O. labiatum has potent anti-inflammatory and antioxidant activity. This work encourages further investigations of $O$. labiatum's potential use as complimentary medicine in anti-inflammatory and antioxidant therapeutics and provides some empirical data for the already prominent anecdotal use in traditional medicines.

\section{Abbreviations}

AP-1: Activator protein 1; CBA: Cytometric bead array; CUPRAC: Cupric reducing antioxidant capacity; DPPH: 2,2-diphenyl-1-picrylhydrazyl; FRAP: Ferric reducing antioxidant power; L: Interleukin;

MTS: 3-(4,5-dimethylthiazol-2-yl)-5-(3-carboxymethoxyphenyl)-2-(4-sulfophenyl)2H-tetrazolium, inner salt; MTT: 3-(4,5-dimethylthiazol-2-yl)-2,5-

diphenyltetrazolium bromide; NF-kB: Nuclear factor kappa B; NMR: Nuclear magnetic resonance; NO: Nitric oxide; PBMCs: Peripheral blood mononuclear cells; ROS: Reactive oxygen species; RT-CES: Real time cell electronic sensing; TNF: Tumour necrosis factor.

\section{Competing interests}

The authors declare that they have no competing interests.

\section{Authors' contributions}

DM designed the study; PK conducted the research and wrote the first draft of the manuscript. JJO did the compound's structural elucidation and wrote that section of the manuscript. RB and PF did three of the antioxidant assays and the NF-kB and AP-1 assays and PF further contributed to the writing, editing and updating the entire manuscript accordingly. DM edited and revised the manuscript. All the authors approved and reviewed the data interpretation and wording in the final draft of the manuscript.

\section{Acknowledgments}

This research was supported by the Southern African Biochemistry and Informatics for Natural Products (SABINA), the Technology Innovation Agency (TIA, South Africa), Margaret McNamara Memorial Fund (MMMF), the Namibian Ministry of Education and the University of Pretoria. The School of Chemistry, University of the Witwatersrand is thanked for running the NMR spectra.

\section{Author details}

${ }^{1}$ Department of Biochemistry, Faculty of Natural and Agricultural Sciences, University of Pretoria, Hatfield Campus, Pretoria 0002, South Africa. ${ }^{2}$ Molecular Sciences Institute, School of Chemistry, University of the Witwatersrand, P.O. Box 2050, Johannesburg, South Africa. ${ }^{3}$ Present address: Chemistry \& Biochemistry department, Faculty of Science, University of Namibia, Windhoek 9000, Namibia. ${ }^{4}$ Present address: Department of Traditional Medicine, National Institute for Medical Research, P. O Box 9653, Dar es Salaam, Tanzania. ${ }^{5}$ Present address: Department of Biochemistry, Faculty of Sciences, University of Johannesburg, P.O. Box 524, Auckland Park, Johannesburg 2006, South Africa.

Received: 5 August 2013 Accepted: 4 January 2015

Published online: 20 January 2015

\section{References}

1. Newman DJ, Cragg GM. Natural products as sources of new drugs over the 30 years from 1981 to 2010. J Nat Prod. 2012;75:311-35.

2. Bhatt A, Naidoo Y, Nicholas A. An investigation of the glandular and nonglandular foliar trichomes of Orthosiphon labiatus N.E.Br. [Lamiaceae]. New Zeal J Bot. 2010;48:153-61.

3. Van Wyk B-E, Van Oudtshoorn B, Gericke N. Medicinal plants of south Africa. Pretoria: Briza Publications; 2009.

4. Selvakkumar C, Gayathri B, Vinaykumar KS, Lakshmi BS, Balakrishnan A. Potential anti-inflammatory properties of crude alcoholic extract of ocimum basilicum L. in human peripheral blood mononuclear cells. J Heal Sci. 2007:53:500-5.

5. Singh S, Majumdar DK, Rehan HM. Evaluation of anti-inflammatory potential of fixed oil of Ocimum sanctum (Holybasil) and its possible mechanism of action. J Ethnopharmacol. 1996;54:19-26.

6. Masresha B, Makonnen E, Debella A. In vivo anti-inflammatory activities of Ocimum suave in mice. J Ethnopharmacol. 2012;142:201-5. 
7. Giday M, Teklehaymanot T, Animut A, Mekonnen Y. Medicinal plants of the Shinasha, Agew-awi and Amhara peoples in northwest Ethiopia. J Ethnopharmacol. 2007;110:516-25.

8. Salminen A, Lehtonen M, Suuronen T, Kaarniranta K, Huuskonen J. Terpenoids: natural inhibitors of NF-kappaB signaling with anti-inflammatory and anticancer potential. Cell Mol Life Sci. 2008;65:2979-99.

9. Girón N, Través PG, Rodríguez B, López-fontal R, Boscá L, Hortelano S, et al. Supression of inflammatory responses by labdane-type diterpenoids. Toxicol Appl Pharmacol. 2008;228:179-89.

10. Lyu S-Y, Park W-B. Production of cytokine and NO by RAW 264.7 macrophages and PBMC in vitro incubation with flavonoids. Arch Pharm Res. 2005;28:573-81.

11. Kim D, Yamasaki Y, Jiang Z, Nakayama Y, Yamanishi T, Yamaguchi K Comparative study on modeccin- and phytohemagglutinin (PHA)-induced secretion of cytokines and nitric oxide (NO) in RAW264.7 cells. Acta Biochim Biophys Sin (Shanghai). 2011:43:52-60.

12. Hussein AA, Meyer JJM, Jimeno L. Bioactive diterpenes from Orthosiphon labiatus and Salvia africana-lutea. J Nat Prod. 2007;293-95

13. Pedersen JA. Distribution and taxonomic implications of some phenolics in the family Lamiaceae determined by ESR spectroscopy. Biochem Syst Ecol. 2000;28:229-53.

14. Škrovánková S, Mišurcová L, Machů L. Antioxidant activity and protecting health effects of common medicinal plants. Adv Food Nutr Res. 2012;67:75-139.

15. Valko M, Rhodes CJ, Moncol J, Izakovic M, Mazur M. Free radicals, metals and antioxidants in oxidative stress-induced cancer. Chem Biol Interact. 2006;160:1-40

16. Fang FC. Antimicrobial reactive oxygen and nitrogen species: concepts and controversies. Nat Rev Microbiol. 2004;2:820-33.

17. Mirshafiey A, Mohsenzadegan $M$. The role of reactive oxygen species in immunopathogenesis of rheumatoid arthritis. Iran J Allergy Asthma Immunol. 2008;7:195-202.

18. Nam JS, Cho MH, Lee GT, Park JS, Ahn CW, Cha BS, et al. The activation of NFkappaB and AP-1 in peripheral blood mononuclear cells isolated from patients with diabetic nephropathy. Diabetes Res Cinical Pract. 2008;81:25-32.

19. Wang J, Li G, Wang Z, Zhang X, Yao L, Wang F, et al. High glucose-induced expression of inflammatory cytokines and reactive oxygen species in cultured astrocytes. Neuroscience. 2012;202:58-68.

20. Checker R, Sandur SK, Sharma D, Patwardhan RS, Jayakumar S, Kohli V, et al. Potent anti-inflammatory activity of ursolic acid, a triterpenoid antioxidant, is mediated through suppression of NF-KB, AP-1 and NF-AT. PLoS One 2012; 7:e31318

21. Karin M, Liu Z, Zandi E. AP-1 function and regulation. Curr Opin Cell Biol. 1997;9:240-6.

22. Liu Y, Shepherd EG, Nelin LD. MAPK phosphatases-regulating the immune response. Nat Rev Immunol. 2007;7:202-12.

23. Elenkov IJ, lezzoni DG, Daly A, Harris AG, Chrousos GP. Cytokine dysregulation, inflammation and well-being. Neuroimmunomodulation. 2005:12:255-69.

24. Infante-Duarte C, Horton HF, Byrne MC, Kamradt T. Microbial lipopeptides induce the production of IL-17 in Th cells. J Immunol. 2000;165:6107-15.

25. Williams A, Steffens F, Reinecke C, Meyer D. The Th1/Th2/Th17 cytokine profile of HIV-infected individuals: a multivariate cytokinomics approach. Cytokine. 2013;61:521-6.

26. Paul AT, Gohil VM, Bhutani KK. Modulating TNF-alpha signaling with natural products. Drug Discov Today. 2006;11:725-32.

27. Mosmann T. Rapid colorimetric assay for cellular growth and survival: application to proliferation and cytotoxicity assays. J Immunol Methods. 1983;65:55-63.

28. Mirabelli CK, Johnson RK, Sung CM, Sung C, Faucette L, Muirhead K, et al. Evaluation of the in vivo antitumor activity and in vitro cytotoxic properties of auranofin, a coordinated gold compound, in murine tumor models. Cancer Res. 1985;45:32-9.

29. Fonteh PN, Keter FK, Meyer D. New bis(thiosemicarbazonate) gold(III) complexes inhibit HIV replication at cytostatic concentrations: potential for incorporation into virostatic cocktails. J Inorg Biochem. 2011;105:1173-80.

30. Abassi YA, Xi B, Zhang W, Ye P, Kirstein SL, Gaylord MR, et al. Kinetic cellbased morphological screening: prediction of mechanism of compound action and off-target effects. Chem Biol. 2009;16:712-23.

31. Atienzar FA, Tilmant K, Gerets HH, Toussaint G, Speeckaert S, Hanon E, et al The use of real-time cell analyzer technology in drug discovery: defining optimal cell culture conditions and assay reproducibility with different adherent cellular models. J Biomol Screen. 2011;16:575-87.

32. Marxen K, Vanselow KH, Lippemeier S, Hintze R, Ruser A, Hansen U. Determination of DPPH radical oxidation caused by methanolic extracts of some microalgal species by linear regression analysis of spectrophotometric measurements. Sensors. 2007;7:2080-95.

33. Benzie IF, Strain JJ. The ferric reducing ability of plasma (FRAP) as a measure of "antioxidant power": the FRAP assay. Anal Biochem. 1996;239:70-6.

34. Jimenez-Alvarez D, Giuffrida F, Vanrobayes F, Golay PA, Otting CC, Ardeau AL, et al. High-throughput methods to assess lipophilic and hydrophilic antioxidant capacity of food extracts in vitro. J Agric Food Chem. 2008:56:3470-7.

35. Apak R, Güçlü K, Özyürek M, Çelik SE. Mechanism of antioxidant capacity assays and the CUPRAC (cupric ion reducing antioxidant capacity) assay. Microchim Acta. 2007:160:413-9.

36. Kampa M, Nistikaki A, Tsaousis V, Maliaraki N, Notas G, Castanas E. A new automated method for the determination of the total antioxidant capacity (TAC) of human plasma, based on the crocin bleaching assay. BMC Clin Pathol. 2002:16:1-16.

37. Woodside DG, Mcintyre BW. Inhibition of CD28/CD3-mediated costimulation of naive and memory human $\mathrm{T}$ lymphocytes by intracellular incorporation of polyclonal antibodies specific for the activator protein-1 transcriptional complex. J Immunol. 2014;161:649-58.

38. Fung FY, Li M, Breunis H, Timilshina N, Minden MD, Alibhai SMH. Correlation between cytokine levels and changes in fatigue and quality of life in patients with acute myeloid leukemia. Leuk Res. 2013;37:274-9.

39. Berridge MV, Herst PM, Tan AS. Tetrazolium dyes as tools in cell biology: new insights into their cellular reduction. Biotechnol Annu Rev. 2005; 11:127-52.

40. Masarik M, Gumulec J, Hlavna M, Sztalmachova M, Babula P, Raudenska M, et al. Monitoring of the prostate tumour cells redox state and real-time proliferation by novel biophysical techniques and fluorescent staining. Integr Biol. 2012;4:672-84

41. Gupta VK, Sharma SK. Plants as natural antioxidants. Nat Prod Radiance. 2006;5:326-34

42. Asadullah K, Sterry W, Stephanek K, Jasulaitis D, Leupold M, Audring H, et al. $\mathrm{IL}-10$ is a key cytokine in psoriasis. Proof of principle by IL-10 therapy: a new therapeutic approach. J Clin Invest. 1998;101:783-94.

43. Watkins LR, Maier SF. Glia: a novel drug discovery target for clinical pain. Nat Rev Drug Discov. 2003;2:973-85.

44. Banno N, Akihisa T, Tokuda H, Yasukawa K, Higashihara H, Ukiya M, et al. Triterpene acids from the leaves of Perilla frutescens and their antiinflammatory and antitumor-promoting effects. Biosci Biotechnol Biochem. 2004;68:85-90

45. Akira S, Hirano T, Taga T, Kishimoto T. Biology of multifunctional cytokines: IL 6 and related molecules (IL 1 and TNF). FASEB J. 1990:4:2860-7.

46. Krueger JG, Fretzin S, Suarez-Farinas M, Haslett PA, Phipps KM, Cameron GS, et al. IL-17A is essential for cell activation and inflammatory gene circuits in subjects with psoriasis. J Allergy Clin Immunol. 2012;130:145-54.

47. Von Bonin A, Rausch A, Mengel A, Hitchcock M, Krüger M, von Ahsen O, et al. Inhibition of the IL-2-inducible tyrosine kinase (ltk) activity: a new concept for the therapy of inflammatory skin diseases. Exp Dermatol. 2011:20:41-7.

48. Hueber AJ, Asquith DL, Miller AM, Kerr S, Leipe J, Melendez AJ, et al. Cutting edge: mast cells express IL-17A in rheumatoid arthritis synovium. J Immunol. 2010;184:3336-40.

49. Lock C, Hermans G, Pedotti R, Brendolan A, Schadt E, Garren H, et al. Genemicroarray analysis of multiple sclerosis lesions yields new targets validated in autoimmune encephalomyelitis. Nat Med. 2002:8:500-8.

50. Taylor MD, van der Werf N, Maizels RM. T cells in helminth infection: the regulators and the regulated. Trends Immunol. 2012;33:181-9.

51. Grivennikov SI, Karin M. Inflammatory cytokines in cancer: tumour necrosis factor and interleukin 6 take the stage. Ann Rheum Dis. 2011;70(1):i104-8.

52. Feldmann M, Maini RN. Anti-TNF alpha therapy of rheumatoid arthritis: what have we learned? Annu Rev Immunol. 2001;19:163-96.

53. Osborn L, Kunkelt S, Nabel GJ. Tumor necrosis factor-alpha and interleukin 1 stimulate the human immunodeficiency virus enhancer by activation of the nuclear factor kB. Immunology. 1989;86:2336-40.

54. Beg AA, Finco TS, Nantermet PV, Baldwin Jr AS. Tumor necrosis factor and interleukin-1 lead to phosphorylation and loss of I kappa B alpha: a mechanism for NF-kappa B activation. Mol Cell Biol. 1993;13:3301-10. 
55. Foletta VC, Segal DH, Cohen DR. Transcriptional regulation in the immune system: all roads lead to AP-1. J Leukoc Biol. 1998;63:139-52.

56. Szekanecz Z, Shah MR, Pearce WH, Koch AE. Human atherosclerotic abdominal aortic aneurysms produce interleukin (IL)- 6 and interferongamma but not IL-2 and IL-4: the possible role for IL-6 and interferongamma in vascular inflammation. Agents Actions. 1994;42:159-62.

57. Oxenkrug GF. Interferon-gamma-inducible kynurenines/pteridines inflammation cascade: implications for aging and aging-associated psychiatric and medical disorders. J Neural Transm. 2011;118:75-85.

\section{Submit your next manuscript to BioMed Central} and take full advantage of:

- Convenient online submission

- Thorough peer review

- No space constraints or color figure charges

- Immediate publication on acceptance

- Inclusion in PubMed, CAS, Scopus and Google Scholar

- Research which is freely available for redistribution 